\title{
Invisible Childhoods: Mexican Children Facing the COVID Pandemic
}

\author{
Yolanda Corona-Caraveo and Carlos Pérez y Zavala \\ Research professors, \\ Education and Comunication \\ Universidad Autónoma Metropolitana \\ Sergio Navarro-Montalvo \\ Psychologist, \\ Autismo Emociones A.C.
}

\begin{abstract}
This article provides a brief introduction to the COVID-19 pandemic and its impact on children and adolescents in Mexico. It argues that children have been left behind and made invisible in the actions taken by governments to counteract the contagion. This article also analyzes what has happened as a result of changes regarding confinement, play, the use of streets and public spaces and educational institutions from a children's rights perspective. The results of several studies that have been carried out in our country are mentioned, ending with some recommendations regarding recognition of the important place children hold in our society.

Keywords: confinement, COVID-19, school, public policies for children, children's rights

Full Contact Information for the authors:

Yolanda Corona-Caraveo, Paseo Colorines no. 2, Col. Huilotepec, Tepoztlán, Morelos, México. C.P. 62520, phone: 52777273 8258, e-mail: yolanda.corona.c@gmail.com Carlos Pérez y Zavala, Amsterdam 275-3. Col. Hipódromo Condesa, Cuauhtemoc, C.P. 06100, Ciudad de México, phone: 52 777303 4225, e-mail: cperez49@yahoo.com.mx Sergio Navarro, Av. Hacienda Vistahermosa 16b, Col. Haciendas de Coyoacán, c.p. 04970, Ciudad de México.C.P. phone: 52561500 9747, e-mail: sergionava74@gmail.com
\end{abstract}




\section{Introduction}

Since the spring of 2020, the world's populace has been subjected to the COVID-19 pandemic. While humanity's need to face the lethal effects of contagions worldwide has in a certain way united us, the pandemic has affected our lives in numerous other dimensions as well. The present overwhelms us and hardly allows us to think of a scenario that goes beyond the here and now and the virus has acted as a catalyst for our emergency responses. At all levels - social, group and personal - we are exposed to the presence of unprecedented conditions that act as a magnifying lens, making us reflect on all the expectations, behaviours and decisions we make in our everyday lives. Finally, we see the here and now as if from inside a time capsule where time has stopped, and yet we see through our digital screens how the lives of others circulate in a parallel universe. After a year of generalized quarantine, the ways of life, communication, habits, perceptions of the world, as well as the values behind our relationships, have been severely altered. It is certainly not the first time that we face this type of health crisis since, as Guiomar Huguet Pané points out (2020. p.3),

Disease is intrinsically part of the history of mankind. We are currently suffering from the coronavirus, but since human beings began to organize themselves in society and to create nuclei of people living together in the same territorial space, contagious diseases took on a special role. As the world population grew, when a disease spread and affected several regions of the planet, becoming a threat to the population, the first pandemics began to be documented. These pandemics sometimes transformed the societies in which they appeared and, quite possibly, have decisively changed or influenced the course of history.

Although the effect of the virus is similar in all countries, it is true that there are certain regions that are more exposed to the risks that this health crisis entails. Poor countries are the first victims due to the precariousness of their health systems and the lack of public policies that are meant to care for their population. The pandemic exposes the conditions of inequality and vulnerable living conditions in broad social sectors and also allows us to evaluate the difficult decisions that some governments have had to make in their efforts to face this catastrophe. Even so, we can say that the population of child and young people is a sector that has remained invisible to public policy makers. Qvortrup (2000) has coined the term "generational apartheid" which refers to the way in which the social organization we currently have has been configured without the participation of children, and therefore, without taking into account their needs at the macro-social planning level.

Reflection and discussion about the impact of the COVID-19 pandemic on children is a relevant topic since children represent at least one third of the world's population. Specifically in Mexico, the sector of children and young people under 18 years of age is $30.1 \%$. Confinement has forced families to carry out their activities through digital screens 
or electronic devices and never before have children and adolescents been confined for so long and without contact with their peers, teachers and family members who are living outside their home environment.

UNICEF's first pandemic report (UNICEF, 2020a) concludes that by the beginning of November, in 87 countries with age-disaggregated data, children and adolescents under the age of 20 accounted for one in nine COVID-19 infections, or $11 \%$ of the 25.7 million infections reported by these countries.

Additionally, the economic crisis caused by COVID-19 threatens to hit children the hardest. The number of children living in multidimensional poverty - without access to education, health, housing, nutrition, sanitation or water - has soared by $15 \%$, or 150 million since mid-2020. (UNICEF, 2020b).

Regarding the situation in Mexico, the invisibility of children to the Mexican government has been evident since no programs have been proposed to address the impact that the pandemic has had on children such as family violence, poverty, excessive school demands and lack of parental care. Over the past year, no programs have been proposed to safeguard their physical integrity, protect them from violence, and accommodate the large number of children who are orphaned due to the deaths of their parents (primarily mothers serving as head of the household). The census of orphaned children by COVID-19 is essential because the government has the obligation to guarantee the rights of all those children who are left unprotected by the death of their parents. However, the government has ignored the rights of children and young people to express their opinions and to be consulted in the elaboration of specific programs of attention for them; at present there is no proposal to collect data on children in this situation, nor are there public policies or specific care programs for them. This becomes more relevant in our country because, in terms of family configuration, there are a large number of single-parent families in which the woman is the head of the family (Aguilar, 2016; INEGI 2020). It is therefore necessary for the government to implement a registration policy that accounts for children who are left unattended.

In the following sections, we will briefly mention some of the physical, emotional, family and social impacts of the confinement and lack of mobility in public spaces of various populations of children and adolescents, enunciated from a rights perspective. We also address the enormous importance of play in different aspects of children's development and especially in the resilience they can have in the face of traumatic situations and uncertainty. Subsequently, we analyze the virtual education policy that replaced face-toface activities in schools. This policy has had great costs in terms of school dropout and educational quality, besides being one of the factors that has generated greater anxiety and stress in children and their families. Following the approach of children's right to express their opinions and to participate, the article concludes by including some eloquent testimonies from children who participated in a previous study conducted in 2020 by one of the authors (Corona, 2021) and supported by three virtual surveys that were conducted in our country. 


\section{Impact on the fulfillment of the rights of children and youth during confinement by COVID-19}

In Mexico, the situation in which children are living is upsetting because the preventive measure of confinement implies a direct impact on their development. In March and April 2020, the United Nations (UN) warned about the physical, psychological and emotional impact that confinement would have on children. Specifically, in emotional terms, it must be taken into account that young children cannot clearly understand what is happening, and therefore may interpret not leaving the house as a punishment for something they have done wrong. All children should receive information and, at the same time, consolation for the anxiety caused by not going out and not seeing their friends.

During the emerging situation, some children's rights have been neglected and it is very clear that the confinement scenario has meant a step backwards in terms of the fulfillment and guarantee of their rights. It is worrisome that the advances in the field of child participation that had been observed in the last three decades, disappeared almost immediately with the appearance of the pandemic. In the face of this emergency, neither governments nor school authorities or parents have bothered to seek knowledge and understanding of the difficult experiences children are going through (REDIM, 2020). As a result, there is little consideration of the differentiated impact that our children are suffering.

Not only does the pandemic put mobility at stake, it is also the primary impediment that hinders and violates other children's rights such as the right to play, rest, health, cultural activities and more. Socialization, play, participation, and other activities are crucial for children's sense of identity and healthy development. According to the Human Rights Commission of Mexico City, confinement is having direct effects on their development process and implies an important effect in psychological and relational terms. Therefore, the commission recommends recognizing children as a group requiring priority attention and emphasizes the need to take necessary measures to guarantee children's rights and meet their best interests (CDHCM, 2020). ${ }^{\mathrm{i}}$

The fact that children's rights have been violated and their experiences have not been taken into account during the pandemic hinders their participation as agents of change, makes their lives more precarious than ever, and impedes progress in terms of public policy that would allow authorities to address the current situation based on children's testimonies.

Another pressing problem of confinement has been the effect that elevated poverty

levels have had on women and children who have been exposed to increased violence in the domestic sphere. In addition to isolation and overcrowding, family incomes have been reduced and subjected to significant instability. This has noticeably altered the mood of parents and caregivers who have become more irritable with greater tendency to react violently (Arteta, 2020; RNR, 2020). Figueroa and Toledo (2020:11) also state that "the confinement measures have led to situations of extreme violence." According to the 
National Shelter Network (Red Nacional de Refugios) 2020 report, after four months into the confinement, violence against women, girls, boys, and adolescents had increased $81 \%$, compared to the same period in 2019. During the first two months since the confinement, the shelters and their Outreach centers, Emergency Houses, External Care Centers, and Transition Houses have accompanied and cared for 6,978 women and children (35\% girls and boys). This number had risen to 14,599 women with their daughters and sons between March and June. The network insisted that "macho" violence is seriously affecting children, "as $48 \%$ of the daughters and sons of the women who requested support were victims of violence in their homes during confinement, and 5\% of the children were victims of sexual abuse" (p.15), again demonstrating that not all mexican families are safe refuges.

As we have seen, the pandemic has brought to light a range of issues that have not yet been adequately addressed by the authorities. Whatever the circumstances, the rights of children cannot wait, much less be overridden. Although governments have been overwhelmed by the circumstances, we must remember that it is their duty to guarantee "the best interests of the child," as postulated in the CRC.

\section{Consequences of confinement on children's play: the loss of street and public spaces}

We start from a perspective that recognizes the importance of play for children. Research in psychology and pedagogy has explored the relationship play has in the optimal development of children, the benefits that its use implies for teaching and learning processes, as well as play's importance in cultivating cognitive, physical, social and emotional skills (Bruner 2010; Bjorklund, 1998). Strauss and Allen, (2006), as well as Isen and Reeve, (2006) have suggested that the emotional states generated during play allow children to have a greater range of creative responses to the problematic situations they experience. The authors have also explored the way in which play offers children the opportunity to partake in physical exercise, which helps them have better resistance and more control of their body movements, It should be taken into account that physical activity for children strengthens their self-esteem, has a direct impact on their weight, motor skills and, therefore, on their general state of health. In this sense, confinement has more serious repercussions in this population group. In addition, it is possible that, for economic reasons, they are not eating healthily either. ${ }^{\mathrm{ii}}$ On the other hand, play allows children to cope with uncertainty and handle traumatic or distressing situations, which increases their resilience. In terms of social skills, play facilitates group learning while allowing children to develop negotiation and decision-making skills. (Corona, 2013, Lester \& Russell, 2008)

Another aspect related to the positive emotions produced by play has to do with the capacity to create imaginary worlds (Lester \& Russell, 2010; Ferrandiz, 2014; Winnicott 1993). These authors have posited the way in which creative ability is related to the capacity to feel alive, to feel free and to develop intuition, fantasy and imagination. People who have renounced to these abilities have given up their own humanity. Creating possible 
worlds through play enables children to imagine a different reality, more bearable than the present one. The game is then configured as a partial escape from reality to momentarily elude the suffocating confinement; it is an escape route from confinement and its impositions.

The problem that arises is that there is a generalized insensitivity and even blindness amongst adults about the benefits of this playful quality. When children are asked about play, their answers are always that they feel happy when they play and that it is one of the activities they like the most. At the same time, however, they are confronted with the ignorance that some parents and teachers have about the benefits play implies for child development. A few years ago, a team of researchers -of which one of the authors of this article is a member- conducted a survey in eight countries around the world ${ }^{\mathrm{ii}}$ including Mexico, to find out what were the obstacles that prevented children from playing. The first obstacle that emerged was a lack of awareness among adults regarding the importance of play. This resulted in their refusal to allow their children or students to devote themselves to play, giving priority instead to study and work (Shier, 2010).

In General Comment no. 17 on the Right of the Child to Rest, Leisure, Play, Recreation and Participation in Culture and the Arts, emphasis is placed on the importance of the opportunity to play outdoors and to interact with natural environments. Another essential aspect of play cited in the document is that it gives children access to time and space without adult control and management. The General Comment goes on to state that free time offers the important possibility, even if minimal, for children to live and play with other children while free from adults. Free time was found to have an influence on negotiation skills as well as learning about solidarity, reciprocity and social belonging to the peer group. Play also allowed children to strengthen their own agency in the sense of proposing and carrying out what they had decided. (Gomez-Serrudo 2008; Lester \& Russell, 2010)

The loss of access that children and young people have had to public spaces and the street that are so evident in these times of pandemic actually began prior to the start of the pandemic. Sanz Roman (2020) has argued that the loss of the street and public spaces for children began long before the pandemic, probably 40 years ago. Children's presence has greatly diminished in these places and when we see them, it is mostly a tutelary presence. In less than two generations, the freedom to play in the streets, to go to parks or playgrounds unaccompanied by adults has gradually vanished. During this present health crisis, Sanz Roman suggests that children are considered as "vectors of contagion" or "transmitters of the virus," (p. 229) even though it is known that this sector of the population is not so prone to the disease. In this sense, what is happening with the pandemic is one of the last steps to expel them from the streets.

In previous studies (Gülgönen \& Corona, 2019) we have argued that for several decades, the streets and public spaces (parks, squares and gardens) have been considered hostile and dangerous places and therefore children have been confined to closed and private spaces. The main reason that adults have given for preventing children from going 
out and playing in public spaces is insecurity, especially the fear of their children being kidnapped and stolen. As for the reasons given by children to justify that the streets are dangerous, we find various forms of violence that they have witnessed, for example, assaults, shootings, fights, bullying, as well as dangerous people in their surroundings. For them, the street's sole function is for moving from one place to another. Children in the previous study mentioned that, "the street is for dying" because there, children are run over when entering and leaving school. In fact, this is one of the main causes of childhood death in our country (Gülgönen \& Corona, 2015). The introjection of this feeling of fear and insecurity is reinforced by the media which refrains from publishing images of children alone in the streets thus generating and increasing the perception about the danger of public spaces. As a result, there are only a few places where children are allowed to play. With the pandemic, public space has not only been relegated, but can no longer even be used to move from one place to another.

With the restrictions being enforced due to the pandemic, children are now captive subjects, living in a kind of house arrest situation where they are locked up in the house for months, while under the constant surveillance of the adults and older siblings in their family. Play is now seen clearly as a natural act that sides with health. In the face of school and domestic demands as well as the boredom caused by lack of contact with the outside world, the fact that children play during their confinement is a sign of their liveliness of spirit.

The tension between the protection of children and their autonomy is a central point when thinking about spaces for children. We found many testimonies by children who say they have had to spend all day in closed spaces, places they do not like because they cannot play, because they are alone or because they are always being scolded. The lack of consideration in urban planning of spaces for children to play, not only outside the housing units, but also inside the houses was identified in Acapulco, Mexico City, Tijuana and Torreon as a major factor limiting children's ability to play. This indicates that there is a pending issue with the real state companies to take into account the needs of children's play spaces (Corona, Gulgonen, 2010). Most of the popular housing developments do not have open spaces dedicated to children. Meanwhile, the houses themselves do not have ample spaces indoors where children can play. Of course, one consequence of the confinement of the 2020 pandemic is that the alternative playgrounds and green spaces in the city are not accessible to children.

\section{Home schooling: a public policy blunder}

Another area that has been widely affected by the arrival of the pandemic is education. Face-to-face education disappeared in Mexico in April 2020 and, as time has passed, the inequality gaps have become more visible. During the pandemic in Mexico, at least six out of ten children have not received education due to lack of resources to adapt to new ways of learning (CDHCM, 2020) ${ }^{\text {iv }}$. Moreover, at least $10 \%$ of primary and secondary 
school children have dropped out of school (Gutiérrez, 2020). According to the National Institute of Statistics and Geography (INEGI) ${ }^{\mathrm{v}}$ in Mexico, there are 38.3 million children and adolescents under 18 years of age, of which 13.2 million children are of school age. During the pandemic, it is estimated that 628,000 children and young people under 18 will drop out of school, either for economic reasons or because they lack a computer and/or television and internet access that are basic conditions for virtual learning. Acevedo et al. (2020) in their study, "The Educational Costs of the Health Crisis in Latin America and the Caribbean," predicted that Mexico will be the country with the second highest dropout rate among children between six and seventeen years of age, with the percentage of exclusion rising from $18 \%$ in 2020 to $22 \%$ in 2021 . The degree of indifference towards children by the authorities can be seen in the fact that the Secretary of Public Education has given 20 conferences, none of which have been directed to children and adolescents.

The arrival of COVID-19 has brought to light a number of problems that had been occurring for a long time. If the health system had multiple deficiencies, the same could be said about the education system. In terms of the crisis of educational systems in Latin America and the Caribbean (Acevedo et al., 2020, p. 8), Mexico is one of the countries that had minimally established four important factors: 1) connectivity in schools, 2) the existence of digital platforms, 3) the possibility of virtual tutoring, and 4) the existence of digital resource packages.

However, we believe that it is essential to emphasize the setback in terms of the right to participation that is occurring in the school environment during the pandemic. The need for teachers to "comply with the program" has imposed a great pressure on the children that is embodied in an endless series of tasks and demands that are very difficult to meet. What is evident is the lack of an approach that understands and addresses not only the cognitive, but especially the emotional needs that children are facing in this health crisis. Instead of the educational system understanding and addressing the depth of the psychological effects that confinement has had on children, they have become entrenched in school demands, as if we were not in a crisis situation. The virtual proposal in educational terms has also overloaded the work of mothers, who are overwhelmed by the assignment of new educational responsibilities with their children which are added to the care tasks they are already regularly assigned. This is without taking into account that in Mexico, many mothers are heads of household whose income comes from activities they perform in the informal sector which is the sector that has been most affected by the preventive isolation measures. The most serious missing piece is that the authorities are not generating data on what is happening in the realm of education in populations of children living in rural areas, or who live in situations of vulnerability.

Teachers and parents must be encouraged to adopt an approach to child protection that has a broader horizon in the sense of considering above all, the well-being of children; that is to say, positive protection that favours their development instead of giving priority to cruel and unrealistic institutional demands. 


\section{Trauma: The under-recognized effect of confinement, plus changes in school and domestic settings}

In terms of school-age children, it should be noted that in contrast to pre-schoolers, their moral development allows them to think about others rather than themselves. They may worry about what might happen to others and feel the need to make sure their parents do whatever is necessary to ensure nothing happens to them. Since they also have a welldeveloped sense of the future, they may develop fears of what might happen to them or their families. As we will see in the later discussion, one of the most commonly expressed fears held by children is that one of their family members will die. Another concern of theirs is that they will run out of money and therefore not have enough to eat.

Even though the psychological effects of confinement have been seen, little has been said about the fact that for many children, this event is truly traumatic. Trauma is spoken of as referring to some experience that is so overwhelming that it produces a disturbance and a sense of being completely helpless and hopeless. (Levine \& Kline, 2016) What has been found is that the younger the child, the more likely he or she is to be overwhelmed by events that might not affect older children or adults. However, the long duration of such a confinement, the information they receive, and the sense that they do not know when it will end, has had an effect to overwhelm and create a sense of hopelessness on both younger and older children. For instance, in the 2020 research study noted above, a six-year-old girl said,

I can't play because they give me a lot of homework, and I get bored, and my mom scolds me because I don't hurry. That's why my heart hurts as if it were being squeezed, so I hide in my room and start crying. Sometimes I draw a picture for my mom and dad to let them know that they broke my heart, and I open the door and throw it at them.

This girl's mother tells us that her behaviour has changed a lot and that she continually hides in order to cry. We certainly cannot yet assess the possible trauma experienced by the children as the consequences may not become sufficiently evident until after a certain period of time. Another 10-year-old commented to us,

I'm locked up, bored and stressed because I can't go out and because of all the homework I have to do, and I get desperate because I don't know when it's going to end. I think I'm going to fail and I'm not going to be able to see my friends anymore. At first, I was happy because I thought I was going to have 40 days of vacation, but now I don't know when it's going to end.

An eleven-year-old girl shared the following, 
With the pandemic my emotion is always more anger than sadness and happiness. It's almost always anger. Anything they say to me I get angry,' go do your homework', pick this up', things like that. And what scares me is that there will never be a cure and that I will have to be locked up for the rest of my life. It would be terrible to no longer be able to be free, to go out wherever you want, whenever you want. (Corona, 2021)

As can be seen in the above testimonies, these children express feeling overwhelmed for various reasons. They also express their fear that the pandemic is a situation that will last forever, without them having the possibility to do anything. We can confidently say that this confinement for more than a year has truly been a traumatic experience for most of the children.

On the other hand, we have already mentioned the way in which violence has increased during the pandemic. Specifically, adult family member abuse towards children is the most common violence experienced by girls and boys (RNR, 2020). Many times, boys and mainly girls are physically attacked by parents, stepparents or siblings and many times they are paralyzed when witnessing a scene of violence, or they hide and try to be invisible in order to escape from being the object of violence themselves. Apart from physical aggression, psychological violence, bullying and threats are behaviours that overwhelm children, rendering them unable to express what is happening to them.

The Committee on the Rights of the Child, through General Comment No. 13 (UN, 2013), raises the devastating effects of violence against children, ranging from physical health problems, developmental delay, learning difficulties and some psychological and emotional consequences such as rejection, fear, anxiety and self-esteem problems. In more serious cases it affects mental health causing anxiety and even suicide attempts. In the consultation made to children in 2018 , children mention that the type of violence they have received had to do with hitting, rudeness or being made to feel bad. Certainly, physical violence is the one that represents a greater risk in the sense that it can escalate and endanger the safety and even the lives of children; however, one cannot minimize the highly destructive effect of verbal and psychological violence which can range from contempt, bullying and ridicule, to threats, isolation and making them feel that they should never have been born or that they should be dead. Within psychological violence we must also include neglect, since it has to do with ignoring children's affective needs, school performance, friendships, neglecting food, clothing and other needs. (Alvarez y Castillo, 2019; Gómez Plata et al., 2020). 


\section{Recovering the voices of children: What do children think about COVID- $19 ?$}

Before continuing to address the experiences of children in these times of pandemic, we would like to note that, in the face of the crisis that the country and the world are currently undergoing, we are experiencing a rupture in the models prescribed in society. The emerging panorama challenges us and makes us question whether the current theoretical and methodological models can understand the complexity of the changes and transformations produced by COVID-19. Faced with this changeable, inconsistent and uncertain scenario, it is of vital importance to rely on the testimonies of the children who tell us about the intense changes they have been living through and that, in some way, have modified their way of conceiving the world.

With the arrival of COVID-19, decisions have been made that directly involve the children's sector without taking into account their experiences and opinions. The fact that children are locked up at home means much more than protecting them from a virus because for them, socialization is one of the main axes of development. Even when children share many situations, they also live diverse experiences within their homes and face their own particularities and vicissitudes. It is important to know what their opinions are about COVID-19. Knowing what their concerns, fears or desires are will help us to understand how they have experienced confinement firsthand. By talking about their experiences, children are not only sharing their experiences and opinions, they are also helping adults understand their perceptions and the impact this situation is having on their own subjectivity.

The next section reports on the results of a supportive accompaniment research project with 45 urban middle-class children aged six to twelve years (20 boys and 25 girls) that was done through telephone interviews during the month of August 2020, by one of the authors (Corona, 2021). The objective was to allow the children to talk about the situation they were living in. They were asked how they were doing and if they wanted to talk about something that mattered to them at the time. All the children were very happy to talk about what was going on with them and consistently asked if we could call them back. This seemed to us to show the children's need to vent and relate to someone outside of their family. The data from this work was complemented with three virtual surveys conducted by other organizations? in Mexico, aiming to understand the situation of children and adolescents during the pandemic. One survey was conducted by the Human Rights Commission (CDHCM, 2020) with children and adolescents between 7 and 17 years of age, another by the National System for the Protection of Children and Adolescents (SIPINNA, 2019), with children under six years of age, and the third by the civil society organization Melel Xojobal, which serves working children in the southeast of the country (Melel Xojobal, 2020).

The testimonies allow us to see that the children show full knowledge of the safety and hygiene measures being employed to avoid contagion and spread of the virus. They are 
aware of what the virus can cause, and they express certain concerns about its duration. They respond clearly about the current situation and its confusing changes, expressing that the confinement and the cancellation of school classes are due to this problem.

It is important to consider that in the interviews conducted by Melel Xojobal, most of the children are of Indigenous origin and almost half come from single-parent homes, so they have to work to help the family income. In this sense, there is a difference in their concerns, as more than $65 \%$ of the children said they were worried about earning less money, being left without a job or having to look for another one.

It is necessary to point out the eloquence of the testimonies of children and adolescents in relation to the consequences of living in confinement. For the working children in the Mexican southeast, the labour situation is one of the most important things. For example, a 10-year-old boy mentioned that, "almost no one comes to buy at the market, we sell in our place with my family, but people don't come and we don't have any money." A 14- year-old girl mentioned that with COVID-19, the situation had changed "a lot, in that sometimes when I was paid, I would give my mom money so she could buy her things, but now what I'm paid isn't enough to do that." Or that of another 16-year-old girl who said, "the money was useful for my studies, and it has been difficult because now I don't have my job and I have nothing to pay for internet or what I need for school." (Melel Xojobal, p. 15)

Based on the interviews and the supportive accompanying work we conducted, the emergence of moods ranging from boredom, fear, uncertainty and sadness are evident. Both children and adolescents express their emotional discomfort in the face of the consequences of the pandemic in their daily lives.

A five-year-old girl stated that, "I am very sad in the afternoons because on days when my dad gives his classes online, he doesn't let me participate and asks me to keep quiet, and worse when he is in a meeting. When he has a meeting, I can't even breathe." Several children between six and nine-years old state that their parents or stepparents hit them or their siblings: "I don't like my stepfather hitting me with the belt." "I don't want my dad to hit my little brothers." "Now my dad doesn't have a job and he gets angry about everything. e even kicks me" (Corona, 2021).

There is great concern among the children about the possibility of their loved ones getting sick, and at the same time, a great fear that their parents will lose their jobs and thus may lack income to meet their basic needs. Special mention should be made about the concern they have for their grandparents and the sadness they express about not being able to visit and hug them. For example, an eight-year-old girl said, "my grandfather's sister has already died and I have not been able to go to see my grandparents. I am very afraid that they will also die." Another 10-year-old boy told us, "my dad does not wear a mask and I tell him that he could die because he has to go to work in the subway where many people go" (Corona 2021, p. 5). In comparison to the children, it is important to note that the adolescents we talked with had a much broader perception of the risk conditions in which they find themselves and therefore developed more complex emotions that bring them 
closer to experiencing stress, anguish and anxiety. In the majority of the interviews, the family is seen as a privileged social space where emotions are experienced in a very intense way that in the best of cases, can regulate fears and difficulties in socializing with other people. Some of the testimonies refer to the home as a space of care and where all possible activities and interactions take place. However, many children also stated that they had observed that there are a greater number of arguments within the family. An example of this are the testimonies of children under six years of age. For example, they said that, "what makes me sad is when my parents get mad at each other." "That my parents separated." "My family, it makes me sad when my dad gets mad at my mom or me." "That dad talks ugly to mom and she runs him out of the house." "When my dad scolds me because he gets like the Hulk" (SIPINNA 2020, p. 25). Even though there are not many testimonies that speak of forms of direct family violence towards the children, we think that this absence has to do with the fact that most of the consultations that have been made with them have been on Zoom, and therefore, the probability that their family is listening is very high. We suspect that for this reason, they do not dare to express themselves openly on this subject.

Another area explored by the aforementioned studies has to do with play as a fundamental activity, especially in the case of boys and girls. There is a great, open nostalgia for the closeness with their peers, family and friends with whom they regularly carried out play activities. The children said that they cannot play and that their parents did not let them play too long on the computer. The youngest children said they would like to be able to run and play sports with their friends.

In terms of school activities, the testimonies could not be more discouraging. The expressions of disenchantment, boredom, feeling overwhelmed and unease that distance education generates are experienced at a very unfortunate period. Most complained that they were bored to death in the classes and that they did not understand what the teachers were teaching. They mentioned that they miss going to school and seeing their friends but also their teachers. A boy of 10 said that, "the classes are boring, and the worst thing is that my mom gets mad if I don't do my homework fast, but it's a lot, much more than when we went to school. That makes me very nervous." A first grader told us that, "neither my mom nor I knew how to send the homework and we spent a lot of time without being able to do it. I think they are going to fail me." Finally, several children mentioned that they no longer want to go to school and their mothers confirmed that they cannot support them as they would like because they are working. (Corona 2021, p. 12).

As can be seen in the testimonies, there is a clear difference between the concerns of Indigenous and working children and adolescents compared to those of the middle-class children who took part in the 2020 study. Working children mainly and openly expressed their economic concerns and their inability to help support their families. On the other hand, the children in Mexico City enunciated their emotions in the face of increased situations of aggression within their families, as well as their concerns for the health and well-being of their family members. 


\section{Final reflections}

Faced with the situation we are living in these times, it is necessary to look for ways to question our current system, the relationships we have established with others and with the planet itself. We need a new ecological and social pact at the global level that also includes children who, in the midst of this crisis, have been invisible to governments and health authorities. It is urgent to take measures for the protection of children's rights that respond to the particular situations they are experiencing. In intergenerational terms, it is necessary to establish a relational paradigm that responds to the principle of the best interest of the child as postulated by the Convention on the Rights of the Child, and that recognizes them as social subjects with rights.

In this essay, we have argued that the pandemic has not only exceeded the actions of the different governments to attend to the general population but has also shown us the conditions of vulnerability of certain sectors of the population, such as children. Even when it is argued that children are not at risk of contagion, what is evident is that for them, confinement is a traumatic event that affects them deeply and that will mark their lives in the medium and long term.

Particularly in Mexico, children are direct victims of aggressions by their parents in the domestic sphere, both in terms of physical and psychological violence. Living conditions as they pertain to children's socialization processes have been altered due to the impossibility of going out to school, out on the street and in public spaces. At the same time, the areas of socialization related to recreational activities are practically nonexistent, so they have turned to digital games as a form of entertainment. We mention, on the other hand, that schooling through the media and digital platforms has not met the minimum conditions to facilitate learning and has become a heavy burden due to the multiple and unreasonable demands that teachers and their institutions impose on them.

Faced with these situations, we think that responses are required at the governmental level to address reversing the increase in child poverty, ensuring greater inclusion to support and protect the physical and mental health of children and young people and putting an end to abuse, gender violence and child neglect. We need educational programs that enable children's participation in decision-making. Likewise, support for equal opportunity and access to education for all must be put in place. In terms of children's well-being, it is essential that parents and teachers attend primarily to the emotional needs of children, providing them with the information and comfort they require to be able to process the situation in which they are living. We should consider what the wishes of the children are. Knowing these wishes will allow for inclusion of the needs of parents and teachers, (including their discourses), as well as the needs of the children. Consideration of both adult and child needs will naturally bring adjustment and balance to what is presented and is given the greatest prominence.

We do not yet know the consequences of this time of deprivation and confinement 
that has been really traumatic for the children. However, due to its characteristics, we are certain that it will have significant repercussions in the medium and long term. What we must be aware of is that in order for children to be able to process trauma, there must be an adult available to give them a sense of security and stability. The children need someone who can contain them in the face of the experience they are going through.

It is also difficult to foresee what changes we will experience as a society once this crisis is over, but we can anticipate some of them: the transformation of the ways of coexistence and socialization in all areas, the change of habits and behaviours within the domestic sphere, the change in consumption patterns and many more. What has become evident is that it is essential to build relationships based on balance and respect with our fellow human beings and with nature, which also refers to intergenerational relationships and the role that adults have in this new social order brought about by the pandemic. We have to assume that social structure is built on a daily basis and that adults, authorities and civil society have a collective responsibility towards the new generations.

Finally, we would like to refer to the proposal of Almeida and Ramos do Ó (2020) who invite us to look ahead to see what horizons can be opened after the pandemic. The authors argue that this crisis has really dislocated the way we relate to life and to others and that it is therefore an opportunity to start again. In our case, we think that it gives us the opportunity to renew intergenerational relationships so that we can recognize the importance of childhood in our society.

\section{References}

Acevedo, I., Castro, E. et al (2020). Los Costos Educativos de la Crisis Sanitaria en América Latina y el Caribe, BID, División de Educación, Sector Social.

Aguilar, L. (2016). Mujeres jefas de hogar y algunas características de los hogares que dirigen. Una visión sociodemográfica. Dirección general de Estudios Sociodemográficos y Prospectiva. Consejo Nacional de Población

Almeida, T. y Ramos do Ó, J. (2020). A vida como acontecimiento e a potência do indeterminado em tempos de pandemia para pensar a relação com a infancia. Sociedad e Infancias, 4, p.285-288.

Alvarez, M. Y Castillo, J. (2019). Panorama estadístico de la violencia contra niñas, niños y adolescentes en México, UNICEF México.

Arteta, I. (2020) Animal Político, 29 de abril de 2020, https://animalpolitico.com/2020/04/centros-justicia-mujeres-servicios-contingeniacoronavirus-covid-19/

Bjorklund, D. \& Douglas, R. (1998). Physical Play and Cognitive Development: Integrating Activity, Cognition, and Education, Child Development 69 (3): 604-606.

Bruner, J. (1983). Play, tought, and language, Peabody Journal of education, 60 (3): 6069. 
CDHCM, (2020). Infancias encerradas. Consulta a niñas, niños y adolescentes. Reporte de la Ciudad de México. Recuperado el 15 de marzo de 2021 https://cdhcm.org.mx/infancias-encerradas/

Corona, Y. (2013). El rescate del juego: nuestra responsabilidad colectiva hacia la infancia, Anuario de Investigación, UAM-Xochimilco, Cd. De México, México.

Corona, Y. (2021). Preocupaciones y testimonios de niñas y niños en tiempos de COVID, reporte de investigación, UAM-Xochimilco, Cd. De México, México.

Corona, Y. y Gülgönen, T. (2010). Consulta sobre el derecho de los niños al juego. Anuario de Investigación del Departamento de Educación y Comunicación, UAMXochimico, Cd. De México, México.

Gómez-Serrudo, N. (2008). La vida cotidiana y el juego en la formación ciudadana de los niños, Universitas Humanística, 66:179-198.

Figueroa, W. \& Toledo, C. (2020). DE LOS DISCURSOS A LOS HECHOS: “Violencias contra las mujeres y la ausencia de políticas gubernamentales para garantizar una vida libre de violencia”, Red Nacional de Refugios, Cd. De México, México.

Gómez Plata, M. (2020). Documento de divulgación de la consulta infantil y juvenil 2018, INE, UAM.

Gülgönen, T. \& Corona, Y. (2015). Children’s Perspectives on Their Urba Environment and Their Appropriation of Public Spaces in México City, Children Youth and Environments, Vol. 5 (2):208-228.

Gülgönen, T. \& Corona, Y. (2019). ¿Jugar en la ciudad? La percepción de niñas y niños de la Ciudad de México sobre su entorno urbano. Cadernos de Pesquisa em Educação 21(49):60-80.

Gutiérrez, V. (2020). Aumenta 10\% la deserción escolar por la pandemia, Contraparte, Periodismo en equilibrio, https://contraparte.mx/gobierno/40220-aumenta-10-ladeserci\%C3\%B3n-escolar-por-la-pandemia.html

Huguet Pane, Guiomar. (2020). Grandes pandemias de la Historia. Recuperado el 20 de marzo de 2021, https://historia.nationalgeographic.com.es/a/grandes-pandemiashistoria 15178

Instituto Nacional de Estadística, Geografía e Informática INEGI (2020) Censo de Población y Vivienda 2020, https://www.inegi.org.mx/programas/ccpv/2020

Isen, A. y Reeve, J. (2006). The influence of positive affect on intrinsic and extrinsic motivation: facilitating enjoyment of play, responsible work behaviour and selfcontrol. Motivation and Emotion 29(4): 297-325.

Levine, P. \& Kline, M. (2016). El trauma visto por los niños. Despertar el milagro cotidiano de la curación desde la infancia hasta la adolescencia. Editorial Eleftheria, España. 
Lester, S. y Russell, W. (2008). Play for a Change: Play, Policy and Practice - a Review of Contemporary Perspectives. Londres: National Children's Bureau.

Melel Xojobal (2020). ¿Como viven las niñas, niños y adolescents de San Cristóbal de las Casas la pandemia del coronavirus?, Consulta e Informe Ejecutivo, Sueniños, Tierraroja A.C. y Melel Xojobal.

Qvortrup, J, (2000). Macroanalysis of childhood. En P. Christensen, A. James, Research with children: Perspectives and practices (pp. 66-86). London: Falmer Press.

REDIM (2020). Balance Anual Redim 2020, El año de la sindemia y el abandono de la niñez en México, Red por los derechos de la infancia en México.

Reimers, F. y Schleicher, A. (2020). Un marco para guiar una respuesta educativa a la pandemia del 2020 del COVID-19.

Red Nacional de Refugios (RNR) (2020). Las dos pandemias. Violencia contra las mujeres en México en el contexto de COVID-19. Report prepared for the United Nations Special Rapporteur on Violence against Women, its Causes and Consequences.

Sanz Román, B. (2020). 40 días y 40 años El confinamiento de la infancia más allá de la pandemia, Revista Sociedad e Infancias, 4, 229-234.

SIPINNA (2019). Primer ejercicio de Participación Ciudadana por la Primera Infancia, Reporte de resultados preliminares, Pacto por la Primera Infancia.

Shier, H. (2010). IPA Global Consultations On Children's Right to Play, International Play Association Report.

https://www.researchgate.net/publication/269108153_IPA_Global_Consultations_O n_Children\%27s_Right_to_Play_Report

Strauss, G. y Allen, P. (2006). The experience of emotion is associated with the automatic processing of positive emotional words. Journal of Positive Psychology 1(3): 150159.

UN (2013). General Comment no. 17 on the Right of the Child to Rest, Leisure, Play, Recreation and Participation in Culture and the Arts (Art. 31), Committee on the rights of the Child (CRC). Recuperado el 25 de marzo de 2021 https://www.refworld.org/docid/51ef9bcc4.html

UNICEF (2020a). Evitar una generación perdida a causa de la COVID-19. Recuperado el 21 de marzo de 2021. https://www.unicef.es/prensa/unicef-pide-evitar-unageneracion-perdida-medida-que-la-covid-19-amenaza-con-causar-danos

UNICEF (2020b). A six-point plan to protect our children. Global coordination is urgently needed to prevent the COVID-19 crisis from becoming a child-rights crisis. Recuperado el 21 de marzo de 2021, de: https://www.unicef.org/coronavirus/sixpoint-plan-protect-children

Winnicott, D.W. (1993) Realidad y Juego, Editorial Gedisa, Barcelona, España. 


\section{Notes}

\footnotetext{
i https://cdhcm.org.mx/infancias-encerradas/

ii https://www.animalpolitico.com/2020/04/salud-nutricion-encierro-ninos-mexico/

iii Conducted with The International Play Association (IPA) in Bulgaria, India, Kenia, Japan, Lebanon, Mexico, South Africa and Thailand.

iv In México, only $44.3 \%$ of households have a computer and only $52.9 \%$ have acces to internet through a fixed or mobile connectionde (REDIM 2020).

${ }^{v}$ INEGI, National Occupation and Employment Survey. IV quarter 2018. Database.

https://www.inegi.org.mx/programas/enoe/15ymas/default.html
} 